\title{
DAYA REPELAN MINYAK ATSIRI CENGKEH, PALA DAN SELEDRI DALAM SEDIAAN LOSION TERHADAP NYAMUK Aedes aegypti
}

\author{
Ririn Teguh Ardiansyah ${ }^{1}$, Susi Iravati ${ }^{2}$, Damar Tri Boewono ${ }^{3}$ \\ ${ }^{1}$ Akademi Kesehatan Lingkungan Mandala Waluya Sulawesi Tenggara \\ ${ }^{2}$ Fakultas Kedokteran Universitas Gadjah Mada \\ ${ }^{3}$ Balai Besar Penelitian dan Pengembangan Vektor dan Reservoar Penyakit, Salatiga. \\ ririn.teguh110388@gmail.com
}

\begin{abstract}
Abstrak
Demam berdarah dengue (DBD) adalah penyakit virus, dapat menimbulkan kematian penderita dalam waktu hanya beberapa hari dan ditularkan oleh nyamuk Aedes aegypti. Repelan botani merupakan salah satu bahan yang digunakan untuk mengurangi gigitan nyamuk. Tujuan penelitian ini adalah untuk mengetahui daya repelan minyak atsiri tanaman Cengkeh (Syzygium aromaticum, L.), Pala (Myristica fragans Houtt) dan Seledri (Apium graveolens L.) dalam sediaan losion terhadap gigitan nyamuk Aedes aegypti. Penelitian ini merupakan jenis penelitian eksperimen murni dengan tahapan pengujian antara lain uji kontrol negatif, uji pendahuluan, dan uji sebenarnya, dengan mencobakan tangan yang telah diolesi bahan uji dan memasukkannya ke dalam sangkar nyamuk. Minyak atsiri tanaman Cengkeh, Pala, dan Seledri dalam sediaan losion terbukti dapat berfungsi sebagai repelan terhadap gigitan nyamuk Aedes aegypti. Effecive Dose 50 (ED50) terhadap nyamuk Aedes aegypti untuk masing-masing repelan minyak atsiri yang dicobakan antara lain; cengkeh 5,25\%, pala 9,69\%, dan seledri 12,06\%, hasil ini menunjukkan repelan minyak atsiri cengkeh paling efisien diantara bahan yang diujikan. Effective Time 50 (ET50) terhadap nyamuk Aedes aegypti untuk masing-masing repelan minyak atsiri yang dicobakan antara lain; cengkeh 2 jam 45 menit, pala 2 jam 24 menit, dan seledri 1 jam 58 menit, hasil ini menunjukkan repelan minyak atsiri cengkeh mampu memberikan perlindungan lebih lama terhadap gigitan nyamuk dibandingkan dengan pala dan seledri. Urutan repelan minyak atsiri mulai dari yang terbaik adalah cengkeh, pala, kemudian seledri.
\end{abstract}

Kata Kunci : repelan, minyak atsiri, cengkeh, pala, seledri, losion, Demam Berdarah Dengue, Aedes aegypti

\begin{abstract}
Dengue is virus disease, it can cause mortality of patients in a few days and it is transmitted by Aedes aegypti mosquito. Botanic repellent is one of materials used to reduce mosquito bite. Objective: To find repellent potency of essential oils of clove (Syzygium aromaticum, L), nutmeg (Myristica fragans Houtt) and celery (Apium graveolens L.) in lotion preparation against Aedes aegypti mosquito bite.This research is true experimental with test stages such as negative control test, preliminary test, and real test, by experimenting hands which had been smeared by test material and entered the hands into mosquito cage. Essential oils of clove, nutmeg and celery in lotion preparation were found functioning as repellent against Aedes aegypti mosquito for each repellent of essential oils which were experimented such as $5.25 \%$ clove, 9.69\% nutmeg and 12.06 celery; these results indicated that repellent of essential oils of clove was most efficient among tested materials. Effective Time 50 (ET50) against Aedes aegypti mosquito for each repellent of essential oils which was experimented were clove for 2 hours and 45 minutes; nutmeg for 2 hours and 24 minutes, and celery for 1 hour and 58 minutes; these results indicated that repellent of essential oils of clove could give longer protection against mosquito bite than nutmeg and celery. Sequence of essential oil repellent starting from the best was clove, nutmeg and celery.
\end{abstract}

Keywords: repellent, essential oils, clove, nutmeg, celery, lotion, dengue, Aedes aegypti 


\section{PENDAHULUAN}

Demam berdarah dengue (DBD) atau Dengue Hemorrhagic Fever (DHF) adalah penyakit virus yang berbahaya, karena dapat menimbulkan kematian penderita dalam waktu hanya beberapa hari. Vektor dengue ditularkan dari orang ke orang melalui gigitan nyamuk Aedes aegypti dan Aedes albopictus. Meskipun merupakan vektor yang sangat baik untuk virus dengue, biasanya Aedes albopictus merupakan vektor epidemic yang kurang efisien dibanding Aedes aegypti ${ }^{1}$.

Untuk mengurangi atau mencegah kontak gigitan, dilakukan dengan berbagai pencegahan, antara lain memakai pakaian yang memadai, memasang kawat kasa pada ventilasi rumah, menggunakan kelambu, memakai zat penolak nyamuk dan penggunaan obat nyamuk ${ }^{2}$. Pencegahan dapat pula dilakukan dengan repelan nyamuk misalnya lotion yang digosokkan ke kulit sehingga nyamuk enggan mendekat. Lotion biasanya mengandung DEET (N, N-diethyl-mtoluamide) dan bahan tanaman pengusir nyamuk seperti daun serai, kayu putih, selasih, zodia dan lain-lain ${ }^{3}$.

Minyak cengkeh (Syzygium aromaticum L.) telah sejak lama digunakan untuk tujuan pengobatan dan gigi dan telah diketahui dengan baik di negara- negara Barat sebagai bahan anestesi gigi. Minyak cengkeh (di Indonesia) adalah produk alami yang tidak mahal dan dapat diperoleh dengan mudah di Asia Tenggara. Minyak cengkeh di Indonesia secara tradisional diproduksi melalui proses distilasi bunga, tangkai bunga, dan daundaun pohon cengkeh.. Komponen yang paling dominan (70-90\%) dan merupakan bahan aktif adalah eugenol ${ }^{4}$. Beberapa hasil penelitian menunjukkan bahwa minyak cengkeh yang mengandung eugenol bersifat sebagai antijamur, antibakteri dan anti serangga ${ }^{5}$.

Tanaman pala (Myristica fragans Houtt) merupakan tanaman asli Indonesia. Berbagai macam bagian dari pala memiliki efek yang bermacam - macam. Sebagai contoh diantaranya adalah biji pala yang dapat dimanfaatkan sebagai obat sedatif-hipnotik dan secara empiris, biji pala sering digunakan oleh masyarakat sebagai obat untuk menenangkan atau menidurkan anak. Minyak pala juga berfungsi sebagai insektisida, fungisida, dan antibakteri ${ }^{5}$.Demam berdarah dengue (DBD) adalah penyakit demam akut (acute febrile illness) yang diakibatkan oleh gigitan nyamuk betina Aedes aegypti serta Aedes albopictus sebagai vector dari virus dengue ${ }^{1}$.
Seledri (Apium graveolens L.) merupakan salah satu sayuran yang populer di dunia dan telah dikenal sejak dulu sebagai jenis tumbuhan liar di dataran Asia. Tumbuhan ini mengandung zat glukosida, apiin, apiol, dan plavonoid yang dapat berfungsi sebagai obat demam, rematik, dan darah tinggi ${ }^{6}$. Seledri menghasilkan minyak yang dapat berfungsi sebagai insektisida ${ }^{7}$.

Penelitian ini bertujuan untuk mengetahui potensi minyak atsiri tanaman Cengkeh (Syzygium aromaticum L.), Pala (Myristica fragans Houtt), dan Seledri (Apium graveolens L.) sebagai repelan terhadap gigitan nyamuk Aedes aegypti.

\section{METODE}

Jenis penelitian ini adalah eksperimen murni (true experiment) karena penentuan subyek secara acak serta variabel yang berpengaruh dalam penelitian dikendalikan dengan desain penelitian yang digunakan yaitu posttest-only control group design $^{8}$ yang bertujuan untuk mengetahui daya repelan dari minyak atsiri Cengkih (Syzygium aromaticum, L), Pala (Myristica fragans Houtt) dan Seledri (Apium graveolens $L$ ) terhadap nyamuk gigitan nyamuk Aedes aegypti di laboratorium, yakni dengan mencobakan tangan yang telah diolesi bahan uji dan memasukkannya ke dalam sangkar berisi 50 ekor nyamuk Aedes aegypti, selam 3 menit dan diulangi setiap jam sampai 6 periode. Adapun formula losion yang digunakan adalah:
a. $\mathrm{Cmc}$
$1 \%$
b. Propilen glikol
$2,5 \%$
c. Akuades
$10,0 \mathrm{ml}$

Pertama-tama, terlebih dahulu dilakukan uji kontrol negatif untuk melihat apakah bahan formulasi losion memberikan efek repelan, yaitu kontrol negatif I (tangan naracoba tanpa diolesi apa-apa) dengan kontrol negatif II (bahan losion tanpa penambahan minyak atsiri), kemudian dilakukan uji pendahuluan untuk mencari konsentrasi terbaik yang akan digunakan pada uji sebenarnya, Adapun konsentrasi yang diuji yakni minyak atsiri cengkeh mengunakan konsentrasi $1 \%$, $2 \%, 4 \%, 6 \%, 8 \%$, dan $10 \%$, sedangkan minyak atsiri pala dan seledri menggunakan konsentrasi $2 \%, 4 \%$, $6 \%$, $8 \%, 10 \%$, dan $12 \%$.

Pada uji sebenarnya, konsentrasi minyak atsiri yang digunakan adalah konsentrasi yang ditetapkan dari hasil uji pendahuluan, dengan cara menetapkan 1 konsentrasi baru. Pada uji ini dilakukan dengan 4 kali replikasi (pengulangan). Untuk menghitung daya proteksi repelan masingmasing ekstrak, yaitu menggunakan metode: 
Jurnal Ilmiah Mahasiswa Kesehatan Masyarakat Vol. 5/No. 3/Juli 2020; Issn: 2502-731X

$\mathrm{p}=$ Daya proteksi

$$
p=1-(T / C)=(C-T) / C
$$

$\mathrm{T}=$ jumlah nyamuk yang hinggap / menggigit pada uji repelan

$\mathrm{C}=$ jumlah nyamuk hinggap / menggigit pada uji kontrol $^{9}$

Selanjutnya data yang diperoleh dianalisis secara statistik. Analisis statistik yang digunakan antara lain pada uji kontrol negatif dengan menggunakan Independent-Sample t-Test untuk membuktikan tidak adanya pengaruh bahan pencampur minyak atsiri, pada uji pendahuluan dengan Probit-Plane Regression Analysis untuk menentukan konsentrasi yang akan digunakan pada uji sebenarnya, dan pada uji sebenarnya dengan Probit-Plane Regression Analysis untuk menentukan waktu efektif repelan masing-masing minyak atsiri dan Two Way Analysis of Varians untuk mengetahui perbedaan rata-rata daya proteksi masing- masing minyak atsiri.

\section{HASIL PENELITIAN}

\section{Uji Kontrol Negatif}

Tabel 1. Perbandingan Rerata Jumlah Hinggapan Pada Kelompok Kontrol Negatif Berbanding Kelompok Kontrol Positif

\begin{tabular}{|c|c|c|c|c|c|c|c|c|}
\hline \multirow{2}{*}{ Dy } & \multicolumn{6}{|c|}{ Pritacini } & \multirow{2}{*}{ Mesar } & \multirow{2}{*}{ 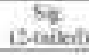 } \\
\hline & 1 & 1 & 3 & 4 & 5 & $a$ & & \\
\hline $\begin{array}{l}\text { Kostivi } \\
\text { Nerzatifi }\end{array}$ & 211 & 211 & 206 & 306 & 240 & 241 & 292.63 & \multirow{2}{*}{0,095} \\
\hline $\begin{array}{l}\text { Rouma } \\
\text { Seznell }\end{array}$ & 210 & 3019 & 200. & 397 & 237 & 283 & 211,33 & \\
\hline
\end{tabular}

Ket. Kontrol Negatif 1: tangan tanpa dioleskan Apapun

Kontrol Negatif 2: tangan dioleskan bahan pembuat losion tanpa penambahan ekstrak

Hasil uji statistik menunjukkan bahwa perbedaan rerata jumlah nyamuk Aedes aegypti hinggap pada kontrol negatif I dan kontrol negatif II adalah tidak bermakna ( $p>0,05)$. Hasil tersebut menunjukkan bahwa bahan pembentuk losion tidak mempunyai efek sebagai repelan dan tidak mengakibatkan bias dalam uji repelan yang dilakukan.

\section{Uji Pendahuluan}

Tabel 2. Daya Proteksi Berbagai Konsentrasi Minyak Atsiri Cengkeh

\begin{tabular}{|c|c|c|c|c|c|c|}
\hline \multirow{3}{*}{$\begin{array}{c}\text { Dowin } \\
\text { (5)in }\end{array}$} & \multicolumn{6}{|c|}{ Dryz Proteicu(to) } \\
\hline & \multicolumn{6}{|c|}{ 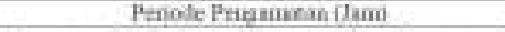 } \\
\hline & 1 & 2 & 3 & 4 & 5 & ó \\
\hline 10 & 90 & 53 & $\pi$ & 70 & 80 & 35 \\
\hline 8 & 86 & no & $6 !$ & 50 & 34 & 37 \\
\hline h & 8t & 5? & 50 & 17 & 23 & 14 \\
\hline+ & 89 & 34 & 30 & 32 & 10 & 34 \\
\hline 2 & $\omega$ & 39. & II & 30 & 36 & 0 \\
\hline 1 & 81 & 57 & 42 & 13 & 24 & 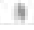 \\
\hline
\end{tabular}

Tabel 3. Daya Proteksi Berbagai Konsentrasi Minyak Atsiri Pala

\begin{tabular}{|c|c|c|c|c|c|c|}
\hline \multirow{3}{*}{$\begin{array}{c}\text { Bosis } \\
\mathrm{Cov})\end{array}$} & \multicolumn{6}{|c|}{ 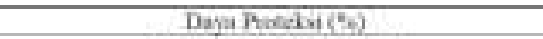 } \\
\hline & \multicolumn{6}{|c|}{ Peronde Perequmeran Danis } \\
\hline & 1 & 2 & 3 & 4 & 3 & 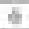 \\
\hline 12 & 87 & is & 7 & 60 & 43 & m) \\
\hline 10 & 80 & 61 & 50 & 39 & 38 & 33 \\
\hline $\mathrm{B}$ & 88 & ti. & 32 & 20 & it & 9 \\
\hline 6 & 83 & 67 & 24 & 44 & 33 & 30 \\
\hline 4 & 82 & 77 & 52 & 19 & 26 & 25 \\
\hline 2 & in & 4 & 0 & 2 & 0 & 5 \\
\hline
\end{tabular}

Tabel 4. Daya Proteksi Berbagai Konsentrasi Minyak Atsiri Seledri

\begin{tabular}{|c|c|c|c|c|c|c|}
\hline \multirow{3}{*}{$\begin{array}{l}\text { Eurem } \\
\mid * i=1\end{array}$} & \multicolumn{6}{|c|}{ Daya hotedai (c) } \\
\hline & \multicolumn{6}{|c|}{ Perbode Peigamerna (lami } \\
\hline & I & $z$ & 3 & $i$ & 5 & 6 \\
\hline 12 & 56 & 50 & 70 & 52 & 35 & in \\
\hline 10 & 74 & 34 & 25 & 20 & 27 & 17 \\
\hline 8 & $\pi$ & 69 & 97. & 53 & 26 & 12 \\
\hline$\hat{6}$ & 51 & 78 & 42 & 0 & 19 & II \\
\hline 4 & 6 & 17 & 9 & 0 & 6 & 0 \\
\hline 2 & 14 & 0 & 2 & D & 6 & 7 \\
\hline
\end{tabular}
kemudian dilakukan analisis dengan Probit-Plane Regression Analysis untuk menentukan ED50 dan ED90 dari masing-masing jenis repelan yang dicobakan.

Tabel 5. Probit-Plane Regression Analysis Penentuan ED50 dan ED90

\begin{tabular}{|c|c|c|c|c|c|c|}
\hline \multirow{2}{*}{$\begin{array}{l}\text { letun } \\
\text { Ataki }\end{array}$} & \multicolumn{3}{|c|}{ ED50 Fol } & \multicolumn{3}{|c|}{ EYy0146) } \\
\hline & ED96 & Lewat & Lym & E1950 & Lamve & Cifer \\
\hline Ceregtob & 5.25 & 2.41 & 6.76 & 50443 & 13.55 & 163273 \\
\hline Pais & 96 & 618 & 11.21 & 73.05 & 16.72 & 117.86 \\
\hline Selatsi & 12.06 & 1.22 & 13.66 & 4800 & 17.31 & 66.90 \\
\hline
\end{tabular}

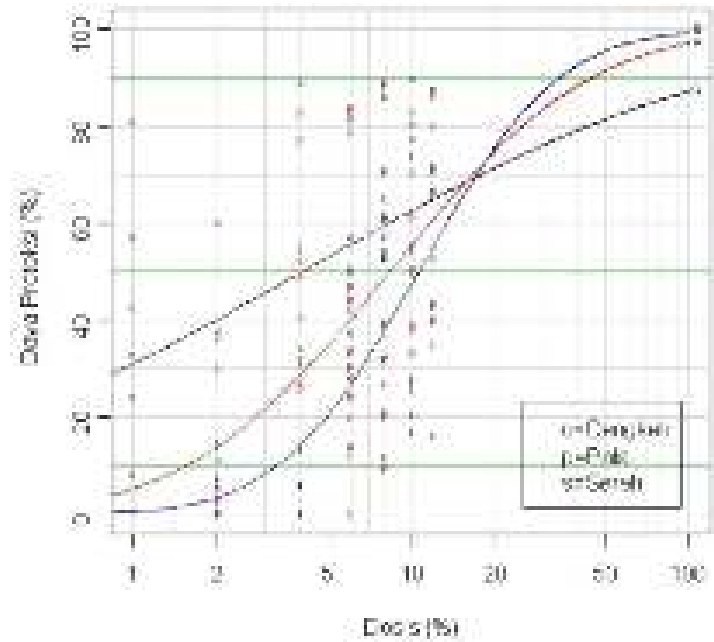

Gambar 1. Grafik Probit-Plane Regression Analysis pada Repelan Minyak Atsiri Cengkeh (-), Pala(-), dan Seledri $(-)$

Berdasarkan data tabel 5 dan gambar 1, maka ditentukan konsentrasi yang digunakan untuk uji sebenarnya adalah dari ED50 antara lain, cengkeh pada konsentrasi $6 \%$, pala pada konsentrasi $10 \%$ dan seledri pada konsentrasi $12 \%$. 


\section{Uji Sebenarnya}

Tabel 6. Rerata Daya Proteksi Setiap Minyak Atsiri Selama 6 Periode Pengamatan Terhadap Nyamuk

\begin{tabular}{|c|c|c|c|}
\hline $\begin{array}{c}\text { Perwode } \\
\text { Peugrmatan (Aam) }\end{array}$ & Repelan & $\begin{array}{l}\text { Replikasi } \\
\text { (N) }\end{array}$ & Mean \\
\hline \multirow{3}{*}{1} & Ceoplet $6 \%$. & 4 & 8683685 \\
\hline & Pab10\% & 4 & .8425130 \\
\hline & Selatri 124 & 4 & 9167338 \\
\hline \multirow{3}{*}{2} & Cengkeb 65 & 4 & 7787200 \\
\hline & Pala $109 \mathrm{~s}$ & 4 & 4859045 \\
\hline & Selodri $12 \%$ & 4 & 6596878 \\
\hline \multirow{3}{*}{3} & Cengket 658 & 4 & 6024550 \\
\hline & Pah10\% & 4 & $68000 \mathrm{kS}$ \\
\hline & Seledh $12 \%$ & 4 & 492135 \\
\hline \multirow{3}{*}{4} & Cengkes 69 & 4 & 5663390 \\
\hline & P2la $10 \%$ & 4 & 5011803 \\
\hline & Seledri $12 \%$ & 4 & 4692315 \\
\hline \multirow{3}{*}{5} & Conbet 65 & 4 & +357105 \\
\hline & $\mathrm{P}_{24} 10 \%$ & 4 & 2101773 \\
\hline & Seluatri $12 \%$ & 4 & 1944130 \\
\hline \multirow{3}{*}{6} & Cenglest 69\% & 4 & 1917405 \\
\hline & Pah $10 \%$ & 4 & 0791828 \\
\hline & 5 elodin $12 \%$ & 4 & -0136303 \\
\hline
\end{tabular}

\section{a. Penentuan ET50}

Hasil pengamatan pada tabel 6 dilakukan uji Probit-Plane Regression Analysis untuk menentukan ET50 dari masing-masing jenis minyak atsiri tanaman uji dapat dilihat pada tabel 7.

Tabel 7. Probit-Plane Regression Analysis

\begin{tabular}{|c|c|c|}
\hline Jein Aikai & FTSO & Rostest he Wakt1 \\
\hline Cenaliet & 2.799 & \pm 2 jain 45 menit \\
\hline Pala & 2,005 & \pm 2 jem 24 mettii \\
\hline Seledn & 1,985? & \pm 1 jam $5 \mathrm{~s}$ meat \\
\hline
\end{tabular}

\section{b. Beda Rerata Daya Proteksi}

Pengukuran beda rerata masing-masing repelan yang dicobakan dilakukan dengan analisis One Way Anova. Berdasarkan hasil deskriptif pada tabel 6, urutan rerata mulai dari yang tertinggi pada masing-masing periode dapat dilihat pada tabel 8 .

Tabel 8. Peringkat Daya Proteksi Setiap Periode

\begin{tabular}{|c|c|c|c|c|c|c|}
\hline \multirow{2}{*}{ No } & \multicolumn{6}{|c|}{ Reninde (finne) } \\
\hline & 1 & 2 & 3 & 4 & 5 & 6. \\
\hline 1 & Sebvini & Costich & Pala & Comaleh & Cenabeit & Cenabli \\
\hline 2 & Cendkeh & Selent & Cengket & & min & \\
\hline 3 & $\mathrm{Pah}$ & Pab & Selenti & Seledit & Selestre & Seloxtn \\
\hline
\end{tabular}
kelompok/perlakuan atau lebih, yang memiliki syarat data berdistribusi normal dan varian data yang homogen ${ }^{8}$. Oleh karena hal tersebut, sebelum melakukan uji lebih lanjut terhadap beda rerata masing- masing repelan maka terlebih dahulu dilakukan uji pada data, hasil pengujian dapat dilihat pada tabel 9.
Tabel 9. Uji Normalitas Kolmogorov-Smirnov

\begin{tabular}{|c|c|c|c|}
\hline \multirow{2}{*}{ Ripielan } & \multicolumn{3}{|c|}{ Kolmopsmw-Simarmes" } \\
\hline & Stotnes & तif & $\mathrm{Sg}$ \\
\hline Cecoked of & 141 & 14 & 200 \\
\hline Pala Ior: & 156 & 24 & 1.34 \\
\hline Selohil\% & 150 & 24 & 170 \\
\hline
\end{tabular}

Uji normalitas diketahui dari nilai Sig. (p-value) uji Kolmogorov- Smirnov. Jika nilai $p>0,05$ maka dapat disimpulkan data berdistribusi normal. Tabel 9 menunjukkan bahwa semua kelompok mempunyai $p>0,05$, sehingga dinyatakan memenuhi syarat normalitas.

Tabel 10. Test of Homogeneity of Variances Setiap Periode Pengujian

\begin{tabular}{|c|c|c|c|c|}
\hline $\begin{array}{l}\text { Periate } \\
\text { Deus: }\end{array}$ & $\begin{array}{l}\text { I crene } \\
\text { 5talssin: }\end{array}$ & 1] & $\$ 12$ & 5.1 \\
\hline 1 & $215 x$ & $z$ & 9 & 335 \\
\hline 2 & 5.252 & 2 & 9 & 031 \\
\hline 3 & 5 silif & 3 & 9 & 1127 \\
\hline 1 & 2.122 & 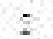 & 9 & $17 \mathrm{c}$ \\
\hline 5 & 7211 & 3 & 9 & 517 \\
\hline 6 & 1.302 & 2 & 9 & .220 \\
\hline
\end{tabular}

Uji homogenitas diketahui dari nilai Sig. ( $p$ value) uji Levene. Jika nilai $p>0,05$ maka dapat disimpulkan kelompok yang dibandingkan adalah homogen. Tabel 10 yang menunjukkan $p>0,05$ adalah kelompok periode 1 , periode 4 , periode 5 , dan periode 6 , sehingga kelompok ini dinyatakan homogen dan dapat dilanjutkan dengan uji One Way Anova, sedangkan kelompok periode 2 dan periode 3 akan dilanjutkan dengan Uji KruskalWallis.

Tabel 11. Uji Beda Antar Kelompok Minyak Atsiri Pada Periode (Jam) Pengujian 1, 4, 5, dan 6 Terhadap Nyamuk Aedes aegypti

\begin{tabular}{|c|c|c|c|c|c|c|}
\hline & & $\begin{array}{l}\text { Sain of } \\
\text { Sarnes }\end{array}$ & if & $\begin{array}{l}\text { YSoin } \\
\text { Sgare }\end{array}$ & F & $8 \mathrm{se}$ \\
\hline \multirow[t]{3}{*}{ Fronde I } & Deforenci Grops & 911 & 3 & 205 & 1.204 & (15) \\
\hline & Withu Conitys & 012 & 0 & int & & \\
\hline & Tioal & 094 & 11 & & & \\
\hline \multirow[t]{3}{*}{ Petrade 4} & Befwoai Compr & .020 & 2 & 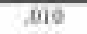 & 4,400 & .045 \\
\hline & Withataniage & a21 & 9 & 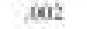 & & \\
\hline & Trat & 0.98 & 11 & & & \\
\hline \multirow[t]{3}{*}{ Fericele 5} & Betwent Gros: & 1166 & 2 & 003 & 2.007 & 100 \\
\hline & Wintin Geaces & 220 & 9 & .024 & & \\
\hline & Tosil & 366 & 11 & & & \\
\hline \multirow[t]{3}{*}{ Fricede of } & Betwoci Cruqu & 985. & $: 2$ & (19:2 & 4,383 & (0) \\
\hline & Winte Goups & ab? & 9 & , 016 & & \\
\hline & Tonal & ITI & 11 & & & \\
\hline
\end{tabular}

Uji beda antar kelompok diketahui dari nilai Sig. ( $p$-value) uji F. Jika nilai $p<0,05$ maka dapat disimpulkan terdapat perbedaan yang signifikan pada kelompok yang dibandingkan. Pada tabel 10 , yang menunjukkan $\mathrm{p}<0,05$ ialah pada Periode 4 , dan periode 6 sehingga terdapat beda nyata daya proteksi cengkeh $6 \%$, pala $10 \%$ dan seledri $12 \%$ pada periode 4 dan 6 . Analisa dilanjutkan dengan Post Hoc Test yang dapat dilihat pada tabel 12 dan 13. 
Tabel 12. Post Hoc Test Periode (Jam) 4

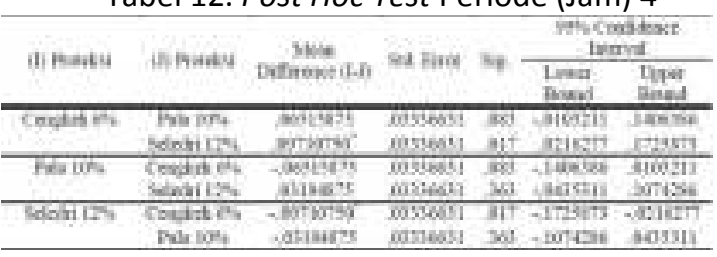

Tabel 13. Post Hoc Test Periode (Jam) 6

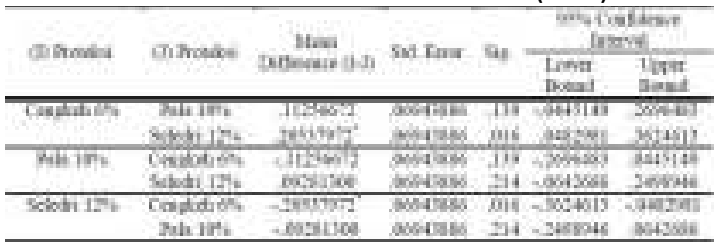

Uji posthoc merupakan kelanjutan dari uji $\mathrm{F}$. Dimana jika uji $F$ signifikan kemudian dapat dilanjutkan untuk uji posthoc. Pada periode ke-4 dan 6 diketahui ada perbedaan daya proteksi pada cengkeh dengan seledri karena hasil uji (tabel 12 dan 13) menunjukkan $p<0,05$, sedangkan cengkeh dengan pala dan pala dengan seledri tidak terlihat signifikan.

Pengukuran beda rerata untuk periode 2 dan 3 dilanjutkan dengan uji Kruskal-Wallis. Hasil uji dapat dilihat pada tabel 14.

Tabel 14. Uji Statistik Kruskal-Wallis

\begin{tabular}{ccc}
\hline & Periode 2 & Periode 3 \\
\hline Chi-Square & 1,192 & 9,269 \\
of & 2 & 2 \\
Asymp. Sip. &, 551 &, 010
\end{tabular}

Uji beda antar kelompok diketahui dari nilai Sig. ( $p$-value) uji Kruskal-Wallis. Jika nilai $p<0,05$ maka dapat disimpulkan terdapat perbedaan yang signifikan pada kelompok yang dibandingkan. Pada tabel 17, yang menunjukkan $p<0,05$ ialah pada Periode 3, sehingga dapat disimpulkan terdapat beda nyata daya proteksi cengkeh $6 \%$, pala $10 \%$ dan seledri $12 \%$ pada periode 3 dan akan dilanjutkan dengan Mann-Whitney Test yang dapat dilihat pada tabel 15

Tabel 15. Uji Statistik Mann-Whitney Test Periode (Jam) 3

\begin{tabular}{|c|c|}
\hline De tieda niriakn & 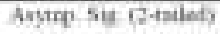 \\
\hline 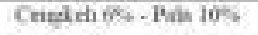 & 021 \\
\hline Coulet or + Sehti $12 \%$ & 945 \\
\hline 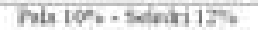 & 021 \\
\hline
\end{tabular}

Mann-Whitney Test merupakan kelanjutan dari uji Kruskal-Wallis. Dimana jika uji Kruskal-Wallis signifikan kemudian dapat dilanjutkan untuk MannWhitney Test. Pada periode 2 diketahui ada perbedaan daya proteksi pada cengkeh dengan pala, cengkeh dengan seledri dan pala dan seledri karena hasil uji (tabel 15) menunjukkan $p<0,05$.

\section{DISKUSI}

Hasil analisis probit pada uji pendahuluan menunjukkan bahwa ED50 yang paling efisien adalah repelan minyak atsiri cengkeh, yaitu pada konsentrasi 5,25\%, kemudian minyak atsiri pala dengan ED50 pada konsentrasi 9,69\% dan ED50 seledri pada konsentrasi $12,06 \%$. Namun dari hasil analisis probit, minyak atsiri cengkeh tidak dapat mencapai ED90, sementara itu ED90 untuk minyak atsiri pala adalah pada konsentrasi $73,06 \%$ dan minyak atsiri seledri pada konsentrasi $48,09 \%$. Hasil ini memperlihatkan adanya perbedaan dosis efektif diantara ketiga bahan tersebut. Ada perbedaan daya penolak nyamuk pada setiap repelan dari tumbuhan ${ }^{10}$. Hal ini memperlihatkan bahwa kandungan bahan kimia yang dikandung pada setiap tumbuhan memberikan efek yang berbeda terhadap nyamuk.

Pada uji sebenarnya, secara statistik tampak bahwa minyak atsiri cengkeh, pala dan seledri memberikan perlindungan terhadap gigitan nyamuk, namun hanya minyak atsiri seledri saja yang mampu menghasilkan daya proteksi hingga $90 \%$, itupun hanya sesaat setelah dioleskan, sementara itu minyak atsiri cengkeh dan pala tidak mampu menghasilkan daya proteksi hingga 90\%. Namun pada hasil pengamatan pada periode selanjutnya daya proteksi repelan minyak atsiri seledri mengalami penurunan secara drastis dibandingkan dengan repelan minyak atsiri cengkeh dan repelan minyak atsiri pala. Hal ini menunjukkan bahwa minyak atsiri seledri memberikan daya proteksi yang kuat terhadap gigitan nyamuk Aedes aegypti namun rentan mengalami penguapan.

Minyak atsiri dari tanaman cengkeh memiliki komposisi senyawa yang teridentifikasi sebanyak 6 golongan utama yaitu eugenol (51,73\%), bicyclo $(38,56 \%)$, phenol $(4,67 \%)$, selinene $(2,88 \%)$, copaene $(1,49 \%)$ dan cubenene $(0,67 \%)^{11}$. Eugenol merupakan komponen terbesar dan yang memberikan aroma khas pada minyak atsiri cengkeh ${ }^{12}$. Eugenol dapat memberikan efek repelan pada nyamuk dan lebah ${ }^{13}$.

Minyak atsiri tanaman pala memiliki komposisi senyawa yang teridentifikasi sebanyak 16 golongan utama, 5 diantaranya yaitu bicyclo $(35,81 \%)$, pinene $(18,57 \%)$, myristine $(15,71 \%)$ dan limonene $(6,91 \%)^{(11)}$. Komponen penyusun utama minyak atsiri seledri adalah limonene (60\%), selinene (10\%), p-cymene, 6-terpineol, b-pinene, b-caryophyllene dan $\alpha$-santalo ${ }^{14}$. Bahan aktif pada minyak atsiri 
yang secara teori memiliki aktifitas repelan pada kedua minyak atsiri tersebut yaitu limonene, senyawa terpenoid ini dapat bersifat sebagai repelan karena memiliki bau yang khas dan menyengat yang tidak disukai oleh serangga ${ }^{15}$.

Syarat suatu zat sebagai repelan adalah harus memiliki titik didih minimal $250^{\circ} \mathrm{C}$ untuk memberikan perlindungan selama 2 jam, senyawa dengan titik didih lebih rendah hanya akan menguap pada kulit hangat, lebih lanjut lagi untuk perlindungan selama 6 jam memiliki syarat titik didih $280^{\circ} \mathrm{C}^{16}$. titik didih untuk eugenol ialah $255^{\circ} \mathrm{C}$, sehingga mampu mencapai ET50 lebih dari 2 jam, sedangkan titik didih limonene ialah $175,4^{\circ} \mathrm{C}$ sehingga memiliki ET50 yang lebih cepat dibandingkan senyawa eugenol, hal yang perlu diperhatikan dalam percobaan ini adalah repelan minyak atsiri pala dan seledri yang memiliki bahan aktif yang sama, yaitu limonene namun dengan efektifitas waktu yang berbeda, dimana pada kandungan limonene pada seledri adalah sebanyak $60 \%$ namun hanya dapat bertahan kurang dari 2 jam, sedangkan minyak atsiri pala yang hanya memiliki kandungan limonene 6,9\% dapat bertahan hingga 2 jam. Perlu diketahui bahwa komponen terbesar dalam minyak atsiri pala adalah bicyclo yang memiliki titik didih hingga $546^{\circ} \mathrm{C}$, senyawa ini kemungkinan mengikat senyawa limonene dan membuatnya dapat bertahan lebih lama pada permukaan kulit. Hampir semua hasil uji repelan minyak esensial yang berasal dari tanaman memperlihatkan proteksi yang pendek, biasanya kurang dari 2 jam $^{17}$. Hasil ini jauh dari standar efektifitas repelan yang telah ditetapkan yang menyatakan bahwa suatu repelan dikatakan efektif apabila waktu penolakannya 6 jam $^{18}$.

\section{SIMPULAN}

1 Minyak atsiri tanaman Cengkeh (Syzygium aromaticum L.), Pala (Myristica fragans Houtt), dan Seledri (Apium graveolens L.) dalam sediaan losion terbukti memiliki daya proteksi terhadap gigitan nyamuk Aedes aegypti. Walaupun hasil penelitian terhadap bahan alami ini menunjukkan hasil yang tidak memenuhi standar repelan menurut Komisi Pestisida Departemen Pertanian RI, yaitu harus memiliki daya proteksi sedikitnya $90 \%$ selama enam jam.

2 Effective Dose (ED) dan Effective Time (ET) minyak atsiri tanaman Cengkeh, Pala dan Seledri terhadap gigitan nyamuk Aedes aegypti:

a. Effecive Dose 50 (ED50) terhadap nyamuk Aedes aegypti untuk repelan minyak atsiri cengkeh pada konsentrasi 5,25\%, pala pada konsentrasi 9,69\%, dan seledri pada konsentrasi $12,06 \%$.

b. Effective Time 50 (ET50) terhadap nyamuk Aedes aegypti untuk repelan minyak atsiri cengkeh ialah 2 jam 45 menit, pala ialah 2 jam 24 menit, dan seledri ialah 1 jam 58 menit.

3. Perbedaan daya proteksi setiap periode pengujian signifikan pada periode 3,4 , dan 6 , dimana pada periode ke-3 repelan minyak atsiri yang paling baik adalah pala, kemudian cengkeh, dan seledri, sedangkan pada periode ke-4 dan 6, repelan minyak atsiri yang paling baik adalah cengkeh, kemudian pala dan seledri. Sehingga disimpulkan bahwa urutan minyak atsiri mulai dari yang terbaik adalah cengkeh, pala, kemudian seledri.

\section{SARAN}

1. Dengan diketahuinya daya proteksi repelan losion minyak atsiri tanaman Cengkeh, Pala, dan Seledri, maka perlu dilakukan penelitian lebih lanjut untuk menguji kemampuan kandungan bahan kimia masing-masing minyak atsiri tersebut sebagai penangkal nyamuk.

2. Perlu adanya penelitian lebih lanjut mengenai bahan emulsi yang tepat untuk sediaan repelan losion minyak atsiri tanaman Cengkeh, Pala, dan Seledri guna meningkatkan daya proteksi masing-masing bahan dan sebagai usaha peningkatan lama waktu proteksi yang dimiliki.

3. Minyak atsiri tanaman Cengkeh, Pala, dan Seledri dapat digunakan sebagai repelan alternatif untuk menangkal gigitan nyamuk Aedes aegypti.

\section{PUSTAKA}

1. Zulkoni, Akhsin. Parasitologi. Nuha Medika. Yogyakarta. 2010

2. Soedarto. Entomologi Kedokteran. EGC. Jakarta. 1990

3. Kardinan, Agus. Tanaman Pengusir dan Pembasmi Nyamuk. PT. Agromedia Pustaka. Jakarta. 2003

4. Tamaru, C.S., C. Carlstrom-Trick, W.J. FitzGerald, Jr. Clove oil, Minyak Cengkeh, a natural fishanesthetic. Sustainable Aquaculture 95', PACON International, Honolulu, Hawaii, 11-14 June. 1995.

5. Trubus. Trubus Info Kit vol-7 Minyak Asiri. Trubus. Depok. 2009

6. Rukmana, Rahmat. Bertanam Seledri. Kanisius. Yogyakarta. 1995

7. Shalaby, M.A., El Zorba, H.Y. Protective Effect of 
Celery Oil, Vitamin $E$ and Their Combination Againts Testicular Toxicity in Male Rats. Global Veterinaria. 2010. 5 (2) : 122-128. Available from <http://idosi.org/gv/gv5 (2)10/9.pdf> [Accesed 8 Februari 2012]

8. Hidayat, A. Aziz Alimul. Metodologi Penelitian Kesehatan Paradigma Kuantitatif, Health Books Publishing. Surabaya. 2010

9. WHO. Guidelines For Efficacy Testing of Mosquito Repellents For Human Skin. 2009. Available from <http://whqlibdoc.who.int/hq/ 2009/WHO_HTM_NTD_WHOPES_2009.4_eng.p df> [Accesed 11 Desember 2011]

10. Tawatsin, A., Asavadachanukorn, P., Thavara, U., Wongsinkongman, P., Bansidhi, J., Boonruad, T., Chavalittumrong, P., Soonthornchareonnon, N., Komalamisra, N., Mulla, M.S. Repellency of Essential Oils Extracted From Plants in Thailands Against Four Mosquito Vectors (Diptera: Culicidae) and Oviposition Deterrent Effects Against Aedes aegypti (Diptera: Culicidae). Southeast Asian J Trop Med Public Health. 2006. 37(5):915- 931. Available from < http://webdb.dmsc.moph.go.th/ifc_nih/applicat ions/files/repellency.pdf> [Accesed 11 April 2011]

11. Ely, Jumarni. Pemanfaatan Minyak Atsiri Beberapa Tanaman Sebagai Larvasida Nyamuk di Laboratorium. Tesis. Universitas Gadjah Mada. Yogyakarta. 2010.

12. Moore, S.J., Lenglet, A.D. Overview of plants used as Insect Repellent. CRC Press. 2004. pp : 344-346. Available from <http://www.sjmoore. net./doc/overview.OverviewofPlantsUsedasInse ctRepellent.pdf> [Accesed 11 April 2011]

13. Kardinan, Agus. Tanaman Penghasil Minyak Atsiri Komoditas Wangi Penuh Potensi. PT Agromedia Pustaka. Jakarta. 2005

14. Kegley, S., Conlisk, E., Moses, M. Marin Municipal Water District Herbicide Risk Assessment. Pesticide Research Institute. Berkeley. 2008. Available From < http://www. marinwater.org/documents/Chap6_CloveOil_8_ 28_08.pdf> [Accesed 12 Juli 2012]

15. Gunawan, Didik. Ramuan Tradisional Untuk Keharmonisan Suami Istri. Niaga Swadaya. Jakarta. 1999

16. Christophers, S. Rickard. Mosquito repellents. Journal of Hygiene. 1947. 45 pp 176-231.

17. Fradin, M. S. Mosquitoes and Mosquito Repellents: A Clinician's Guide. Annals of Internal Medicine. 1998 Available from <http://www.acponline. org/journals/annals/01jun98/mosquito.htm>
[Accesed 8 April 2011]

18. Komisi Pestisida Departemen Pertanian. Metode Standar Pengujian Efikasi Pestisida. Departemen Pertanian. Jakarta. 1995. 